\title{
The site of magnesium absorption from the ruminant stomach
}

\author{
By F. M. TOMAS ANd B. J. POTTER \\ CSIRO, Division of Human Nutrition (formerly Division of Nutritional \\ Biochemistry), Kintore Avenue, Adelaide, South Australia 5000, Australia
}

(Received 27 August 1975 - Accepted 24 November 1975)

\begin{abstract}
I. A low-magnesium diet was fed to four sheep, each of which had been surgically prepared with a rumen fistula, a tube into the cranial one-third of the omasum, a tube to the cranial onethird of the abomasum and a re-entrant duodenal cannula. $\mathrm{Mg}$, as gluconate or acetate, was continuously infused for $12-14 \mathrm{~d}$ in turn into (1) the caudal duodenal cannuia, (2) the abomasum, (3) the omasum, (4) the rumen. A continuous infusion of the chromium-ethylenediaminetetraacetic acid complex (CrEDTA) was maintained to the rumen. The abomasal effluent which flowed through the cranial duodenal cannula was continually sampled and the flow of $\mathrm{Mg}$ calculated from the concentrations of $\mathrm{Mg}$ and CrEDTA. Blood and rumen fluid samples were taken and urine and faeces collected during each period of $\mathrm{Mg}$ infusion.

2. The $\mathrm{Mg}$ infused to either the abomasum or omasum was completely recovered at the duodenum, indicating a lack of net absorption of $\mathrm{Mg}$ from these stomach compartments. In contrast, $13.7-18.7 \mathrm{mmol}(36-61 \%)$ of the $\mathrm{Mg}$ infused to the rumen was not recovered at the duodenum which suggested that a substantial net absorption of the infused $\mathrm{Mg}$ occurred from the reticulo-rumen. Absorption of $\mathrm{Mg}$ caudal to the pylorus was not related to the site of $\mathrm{Mg}$ infusion and averaged $3 \cdot 28 \pm 0.56$ (sEM) $\mathrm{mmol} / \mathrm{d}$.

3. Compared with the intraruminal infusion, the post-ruminal infusion of $\mathrm{Mg}$ was associated with decreased plasma and rumen fluid $\mathrm{Mg}$ concentrations, decreased urinary $\mathrm{Mg}$ excretion, decreased $\mathrm{Mg}$ balance and increased faecal $\mathrm{Mg}$ excretion.

4. It is concluded that no significant absorption of $\mathrm{Mg}$ occurs from either the omasum or abomasum in sheep and that the reticulo-rumen is the principal site of $\mathrm{Mg}$ absorption before the pylorus. Absorption of $\mathrm{Mg}$ post-ruminally is insufficient to maintain normal $\mathrm{Mg}$ status in the animal.
\end{abstract}

With the use of the re-entrant duodenal cannulation technique, it has been found in both cattle and sheep that most of the net absorption of magnesium occurs before the pylorus (Rogers \& van't Klooster, I969; Pfeffer, 'Thompson \& Armstrong, I970; Grace \& MacRae, 1972; Kemp, van't Klooster, Rogers \& Geurink, r973). Although the rumen mucosa has been found to be permeable to $\mathrm{Mg}$ at very high concentrations in the rumen fluid, the average $\mathrm{Mg}$ concentrations normally found are considered to be less than those required to overcome the electrochemical gradient, and measured uptakes from the rumen contents have indicated $\mathrm{Mg}$ absorption from this site to be negligible (Care \& van't Klooster, 1965; Phillipson \& Storry, 1965). Care \& van't Klooster (1965) have also reported that net $\mathrm{Mg}$ absorption from gastric pouches does not occur in the sheep, and this indicates a lack of $\mathrm{Mg}$ absorption from the abomasum. In addition, Pfeffer \& Rahman (1974) have reported an apparent relative lack of absorption of $\mathrm{Mg}$ infused to the abomasum rather than to the rumen.

Based on these findings, the primary site for $\mathrm{Mg}$ absorption before the pylorus appears logically to be the omasum. Harrison (197I) found that the omasal epithelium is permeable to $\mathrm{Mg}$ in vitro, but the unfavourable electrochemical gradient and the 
short period of time the digesta is in the organ are factors which argue against the omasum being of major importance in $\mathrm{Mg}$ absorption.

The present study was undertaken to determine the site(s) of $\mathrm{Mg}$ absorption in the ruminant stomach, and results suggested that this was the reticulo-rumen rather than the omasum.

\section{EXPERIMENTAL}

\section{Animals, housing and diet}

Four Merino ewes, aged 2-5 years and weighing about $40 \mathrm{~kg}$, were used for these studies. They were housed in an air-conditioned room in metabolism cages with facilities for separate collection of urine and faeces, and with rainwater freely available for drinking.

The dietary ration was divided into twelve equal portions which were dispensed at intervals of $2 \mathrm{~h}$ by an automatic feeder. Each daily ration contained $520 \mathrm{~g}$ dry matter made up of $(\mathrm{g})$ : tissue paper 290, starch 106 , casein 60 , molasses 20 , polyethylene pellets 20, mineral mixture 24 (to provide (mg): $\mathrm{Ca}_{3}\left(\mathrm{PO}_{4}\right)_{2} 6480, \mathrm{CaCO}_{3} \mathrm{I} 880, \mathrm{~K}_{2} \mathrm{SO}_{4} 5210$, $\mathrm{KCl} 2860, \mathrm{~K}_{2} \mathrm{HPO}_{4} 2 \mathrm{I} 60, \mathrm{NaCl}_{4560}$, ferric citrate ${ }_{514}, \mathrm{MnSO}_{4} \cdot{ }_{4} \mathrm{H}_{2} \mathrm{O}$ I $50, \mathrm{CuSO}_{4}$. ${ }_{5} \mathrm{H}_{2} \mathrm{O}_{22} \cdot 5, \quad \mathrm{CoCl}_{2} \cdot 6 \mathrm{H}_{2} \mathrm{O}$ r.2, $\mathrm{ZnSO}_{4} \cdot 7 \mathrm{H}_{2} \mathrm{O}_{14} 8, \mathrm{Na}_{2} \mathrm{MoO}_{4} \cdot 2 \mathrm{H}_{2} \mathrm{O} 7 \cdot 3, \mathrm{KI} \quad 0 \cdot 6$, $\mathrm{Na}_{2} \mathrm{SeO}_{4} \mathrm{O} \cdot 2$ ), vitamin mix O.I (to provide $(\mu \mathrm{g})$ : retinol 375, cholecalciferol 6.25). The $\mathrm{Mg}$ content of the dietary components differed between mixed batches, and on analysis the rations were found to provide from 4.2 to $7.0 \mathrm{mmol} \mathrm{Mg} / \mathrm{d}$. In addition, two sheep (nos. 908I and 2054) consistently ate only $400-45^{\circ} \mathrm{g}$ dry matter/d.

\section{Surgical preparation of animals}

Surgical procedures were used on each sheep to establish the following preparations: (I) a rumen fistula; (2) a silicone tube $(2.6 \mathrm{~mm}$ i.d., $4.9 \mathrm{~mm}$ o.d.) into the omasum, projecting $30-40 \mathrm{~mm}$ into the lumen from a point on the greater curvature about $40 \mathrm{~mm}$ from the reticulo-omasal orifice, and secured in position by a method similar to that described by Driedger, Condon, Nimrick \& Hatfield (1970) using a polyesterfibre skirt attached to the tube; (3) a silicone tube into the cranial one-third of the abomasum (Driedger et al. 1970); (4) a re-entrant duodenal cannula about 40-50 mm from the pylorus, with the cannula stems projecting through the body wall in the same dorsal plane about $60 \mathrm{~mm}$ apart.

Post-mortem examination of several preparations showed that the tube into the omasum projected beyond the tertiary lamellae to a position which enabled a solution infused through the tube to enter the cranial one-third of the omasum.

\section{Sampling procedures}

Results of preliminary studies indicated that the $\mathrm{Mg}$ in duodenal digesta collected adjacent to the pylorus (i.e. in the abomasal effluent) was present almost entirely in the fluid $(>98 \%)$ and that representative sampling of only the fluid was needed in order to measure the flow of $\mathrm{Mg}$ to the duodenum. A device was constructed from acrylic plastic such that digesta flowing up a tube $(80 \mathrm{~mm} \times 16 \mathrm{~mm}$ i.d.) connected vertically to the cranial arm of the duodenal cannula would flow through an orifice 
at a height of $60 \mathrm{~mm}$ into another tube $(55 \mathrm{~mm} \times 30 \mathrm{~mm}$ i.d.) connected to the caudal arm of the cannula. A sampling probe ( $5 \mathrm{~mm}$ o.d.) was inserted into the cranial tube, and the device sealed to the atmosphere after setting the level of digesta about $20 \mathrm{~mm}$ below the 'flow-over' orifice. This level was sufficient to cover the probe, but allowed reverse digesta flows to be fully accommodated by the large-bore caudal arm of the device. In this way, only abomasal effluent was sampled.

During the $7 \mathrm{~d}$ sampling period, a portion of duodenal digesta flow was withdrawn continuously at about $0.15 \mathrm{ml} / \mathrm{min}$ from the probe in the sampling device by means of a peristaltic pump. Daily samples were kept separate, and on occasions when sampling was incomplete due to a blockage, the sample was discarded. Urine and faeces were collected separately each day. On $2 \mathrm{~d}$ of the last $4 \mathrm{~d}$ of each sampling period, samples of jugular blood and rumen fluid were taken at 10.00 and 16.00 hours. Additional rumen fluid samples were taken at I0.00 hours on each of the other $5 \mathrm{~d}$ when $\mathrm{Mg}$ was infused to the abomasum or omasum.

Sampling and analytical procedures were the same as those described by Tomas, Jones, Potter \& Langsford (1973) and Tomas \& Potter (1975) except that faeces were dried at $105^{\circ}$ for $24 \mathrm{~h}$ and urine was acidified with hydrochloric acid.

\section{Experimental design}

The experimental design involved the measurement of the flow of $\mathrm{Mg}$ from the cranial arm of the duodenal cannula when supplementary $\mathrm{Mg}$ was infused in turn into the caudal arm of the duodenal cannula, the abomasum, the omasum and the rumen.

The sheep were initially given the experimental diet for an adaptation period of 7-10 d, during which time they received a daily drench of $1.5 \mathrm{~g}$ magnesium oxide/d. After adaptation the Mg supplementation was given as a continuous infusion at about $380 \mathrm{ml}$ magnesium gluconate (magnesium acetate to sheep no. 2054)/d into the appropriate infusion site, in the order duodenum, abomasum, omasum and rumen. The quantities of $\mathrm{Mg}$ infused are given in Table $\mathrm{I}$. An inadvertent error in the preapration of the infusion solutions for sheep no. 2010 resulted in only half the planned quantity of $\mathrm{Mg}$ being infused to this animal.

A continuous intraruminal infusion of a complex of chromium with ethylenediaminetetraacetic acid (CrEDTA) was begun at the same time as the $\mathrm{Mg}$ infusion and maintained throughout the experiment. A period of $5 \mathrm{~d}$ was allowed for digesta $\mathrm{Mg}$ flows to stabilize on each treatment before sampling began. Polyethylene glycol (PEG) was included in the $\mathrm{Mg}$ infusate at a concentration of $5^{\circ} \mathrm{g} / \mathrm{l}$ in order to estimate both contamination of the sampled digesta by infusate during the duodenal infusion, and any backflow to the rumen of infusate directed into the abomasum or omasum. There was a $7 \mathrm{~d}$ sampling period for each infusion site. On the basis of the results from two sheep, the abomasal infusion of $\mathrm{Mg}$ and PEG to the two remaining sheep was witheld subject to the omasal infusion results, and was finally omitted.

\section{Statistical analysis}

The results were analysed as a two-way classification of sheep and treatments in which the two missing values relating to the abomasal infusion were estimated and 
the tests of significance were based on a pooled error with seven degrees of freedom. To determine whether the estimated rates of absorption from infusion into the omasum and rumen were different from zero, the tests were based on the betweensheep variability with three degrees of freedom.

Since the allocation of the treatment order in each sheep was non-random the results were confounded by the sequence of treatments, and the differences in absorption may have been due either to the time or to the site of infusion. On biological grounds no mechanism can be proposed for large differences in absorption due to time and, therefore, it is more probable that the results reflect differences due to the site of infusion.

\section{RESULTS}

\section{Infusate location}

On no occasion was PEG detected in the duodenal sample during $\mathrm{Mg}$ infusion to the caudal arm of the duodenal cannula. This suggested that no significant backflow of infusate to the sampling probe occurred, thus proving the validity of the measured baseline $\mathrm{Mg}$ flow. A backflow of infusate to the rumen was detected in only one sheep during $\mathrm{Mg}$ infusion post-ruminally. Rumen fluid from sheep no. 908I contained from 0.21 to $0.6 \mathrm{I} \mathrm{mg} \mathrm{PEG} / \mathrm{ml}$ during omasal infusion of $\mathrm{Mg}$. The amounts of PEG required to maintain these concentrations were calculated from the extent of dilution of the CrEDTA infused intraruminally, and on this basis, entry of PEG to the rumen from the $18.8 \mathrm{~g} / \mathrm{d}$ infused to the omasum was $\mathrm{r} \cdot 95,3.25,3.84,0$, $O$ and $\mathrm{I} \cdot 66 \mathrm{~g}$ for each of the six consecutive days of the collection period. Hence for the $6 \mathrm{~d}$ period, about 23 of $245 \mathrm{mmol} \mathrm{Mg}$ infused to the omasum of this sheep entered the rumen.

\section{Absorption of $M g$}

Results for the absorption of $\mathrm{Mg}$ from the different stomach compartments are given in Table $\mathrm{r}$. Significant absorption of infused $\mathrm{Mg}$ occurred only from the rumen $(P<0.001)$. Absorption from either the omasum or abomasum was not significantly different from zero $(P>0.05)$. Though not significant, the small apparent absorption obtained for sheep no. 908 $\mathrm{I}$ may have been due to backflow of infusate from the rumen.

The total net absorption of $\mathrm{Mg}$ before and after the pylorus as estimated from $\mathrm{Mg}$ input, duodenal $\mathrm{Mg}$ flows and faecal $\mathrm{Mg}$ excretion are given in Table 2. Except when $\mathrm{Mg}$ was infused to the rumen, there was a net secretion of $\mathrm{Mg}$ before the pylorus $(\mathrm{I} \cdot 35 \pm 0.30 \mathrm{mmol} / \mathrm{d})$ whereas a net absorption from the remainder of the gut was consistently obtained for all infusions $(3.28 \pm 0.56 \mathrm{mmol} / \mathrm{d})$. Total absorption from the whole gastrointestinal tract was $1 \cdot 76 \pm 0 \cdot 70$ and $18 \cdot 65 \pm 2 \cdot 27 \mathrm{mmol} / \mathrm{d}(3 \cdot 75 \pm \mathrm{I} \cdot 75$ and $44.4 \pm 0.44 \%$ of intake) for $\mathrm{Mg}$ infusion post-ruminally and intraruminally respectively.

\section{Excretion and balance of $M g$}

Values for urinary and faecal excretion of $\mathrm{Mg}$, and $\mathrm{Mg}$ balances are given in Table 2. Intraruminal infusion of $\mathrm{Mg}$ was associated with substantially higher $\mathrm{Mg}$ balances, higher urinary $\mathrm{Mg}$ excretion and lower faecal $\mathrm{Mg}$ excretion than was post-ruminal 


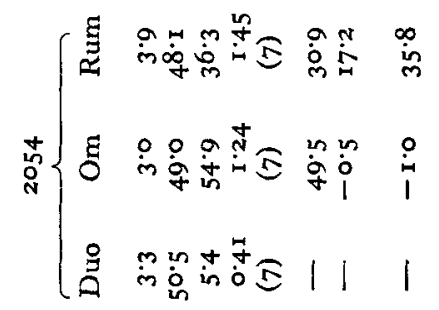

दे

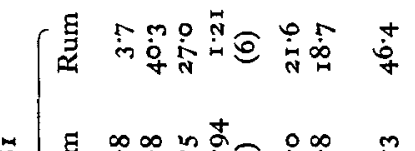

है

$\approx$

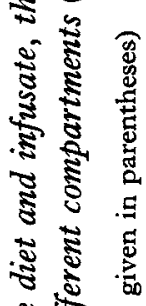

g̊

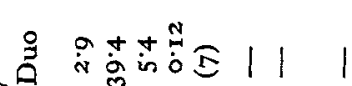

雪

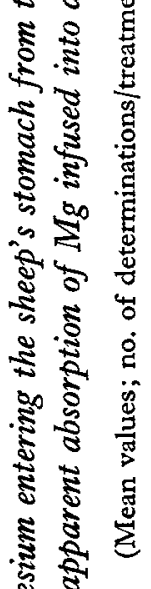

ธิำ

है

है

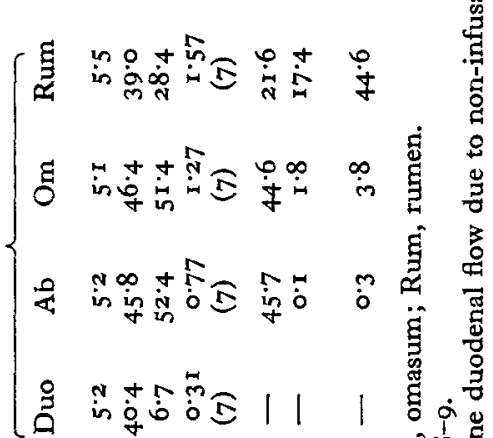
g.

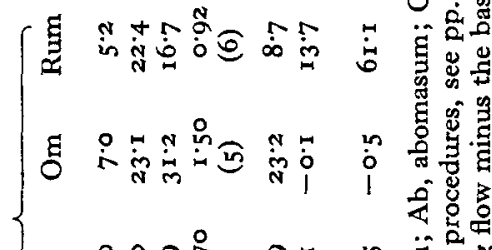

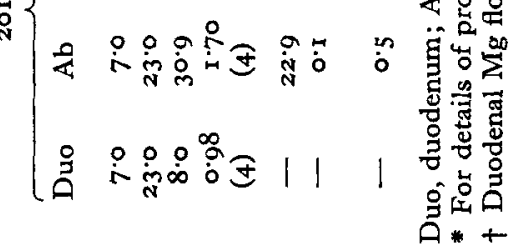

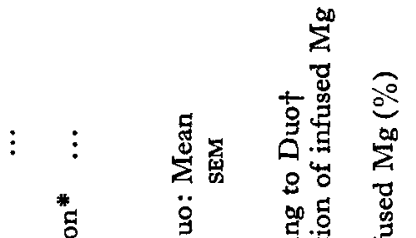

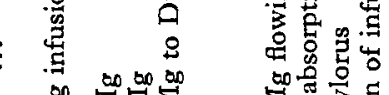

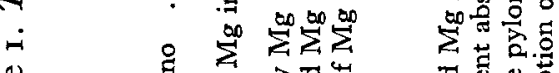

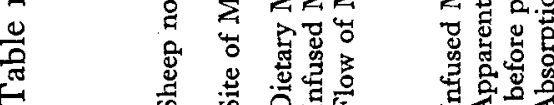


'Table 2. The mean excretion of magnesium in the urine and faeces, $M g$ balance, and the net absorption of $M g$ from the whole digestive tract and the sections before and after the pylorus $(\mathrm{mmol} / \mathrm{d})$

(Mean values for four sheep, except for abomasal infusion where two sheep were used)

$\mathrm{Mg}$ in faeces

$\mathrm{Mg}$ in urine

$\mathrm{Mg}$ balance

Net $\mathrm{Mg}$ absorption

before pylorus

Net Mg absorption

after pylorus

Net $\mathrm{Mg}$ absorption

from whole

digestive tract

Site of $\mathrm{Mg}$ infusion $\uparrow$

\begin{tabular}{ccccc}
\multicolumn{4}{c}{ Site of $\mathrm{Mg}$ infusiont } \\
Duodenum & Abomasum & Omasum & Rumen & SEt \\
42.8 & 38.1 & 41.4 & $23.4^{* * *}$ & 1.60 \\
2.0 & 0.3 & 1.3 & $13.7^{* * *}$ & 1.02 \\
-2.0 & 2.1 & $1.7^{*}$ & $4.9^{* * *}$ & 0.99 \\
-1.8 & -1.2 & -0.8 & $14.9^{* * *}$ & 0.93 \\
1.9 & 3.6 & $4^{*} 1^{*}$ & 3.7 & 0.77 \\
0.1 & 2.4 & 3.2 & $18.6^{* * *}$ & 1.16
\end{tabular}

Mean values were statistically significantly different from those for duodenal infusion: $* P<0.05$, ** $P<0.01$, *** $P<0.001$.

+ For details of procedures, see pp. $3^{8-9}$.

$\ddagger$ SE does not apply to abomasal infusion results.

Table 3. Mean concentrations (mmol/l) of magnesium and calcium in plasma, and of $M g$ in rumen fluid

(Mean values for four sheep, except for abomasal infusion where only two sheep were used)

\begin{tabular}{lccccc} 
& \multicolumn{4}{c}{ Site of Mg infusion $\uparrow$} \\
Rumen fluid Mg & Duodenum & Abomasum & Omasum & Rumen & SE† \\
Plasma Mg & 0.49 & 0.47 & 0.47 & $2.54^{*}$ & 0.68 \\
Plasma Ca & 0.72 & 0.52 & 0.77 & $1.15^{* *}$ & 0.08 \\
& 2.38 & 2.54 & 2.44 & 2.34 & 0.03
\end{tabular}

Mean values were statistically significantly different from those for duodenal infusion: * $P<0.05$, ** $P<0.01$.

$\uparrow$ For details of procedures, see pp. 38-9.

$\ddagger$ SE does not apply to abomasal infusion results.

infusion of $\mathrm{Mg}$. During intraruminal infusion of $\mathrm{Mg}$, urinary $\mathrm{Mg}$ excretion was $32 \cdot 3 \pm 1 \cdot 3 \%$ of $\mathrm{Mg}$ intake and $72 \cdot 8 \pm 2 \cdot 7 \%$ of total net $\mathrm{Mg}$ absorption.

\section{Plasma and rumen fluid samples}

The effect of the different sites of $\mathrm{Mg}$ infusion on the plasma calcium and $\mathrm{Mg}$ levels is indicated in Table 3 . Infusion of $\mathrm{Mg}$ post-ruminally was associated with reduced plasma and rumen fluid $\mathrm{Mg}$ concentrations in comparison with the intraruminal infusion. Plasma $\mathrm{Ca}$ concentrations were unaffected by treatment. 


\section{DISCUSSION}

It is clear from the results presented here that practically all the net $\mathrm{Mg}$ absorption which occurs before the pylorus in sheep is from the reticulo-rumen. Indeed, in these experiments absorption from this stomach compartment accounted for $70-9 \mathrm{x} \%$ of the total $\mathrm{Mg}$ absorption from the gastrointestinal tract. Only very small amounts, if any, are absorbed from either the omasum or abomasum. Rogers \& van't Klooster (r969) concluded from the results of reported studies (Stewart \& Moodie, I956; Care \& van't Klooster, 1965; Phillipson \& Storry, 1965) that absorption of $\mathrm{Mg}$ from the reticulo-rumen is negligible, except at very high concentrations of $\mathrm{Mg}$ in the rumen fluid. However, Care \& van't Klooster (1965) had reported an absorption rate of $0.165 \mathrm{mmol} \mathrm{Mg} / \mathrm{h}$ from the reticulo-rumen contents of an anaesthetized sheep in which the rumen fluid level of $\mathrm{Mg}$ was $\mathrm{I} \cdot 75 \mathrm{mmol} / \mathrm{l}$. This rate is equivalent to $3.96 \mathrm{mmol} / \mathrm{d}$, which is indeed a significant quantity. In normal physiological conditions and with a more usual $\mathrm{Mg}$ concentration in rumen fluid of $2.5 \mathrm{mmol} / 1$ (Storry, 1961; Rogers \& van't Klooster, 1969; Tomas \& Potter, 1975), a substantial absorption of $\mathrm{Mg}$ from this organ could be envisaged. In the present work, the $\mathrm{Mg}$ levels in the rumen fluid samples taken during the infusion of $40-50 \mathrm{mmol} \mathrm{Mg} / \mathrm{d}$ to the rumen were $2 \cdot 2-3.6 \mathrm{mmol} / 1$ and were associated with a net absorption of $15 \cdot 6-17 \cdot 7 \mathrm{mmol}$ $\mathrm{Mg} / \mathrm{d}$ from the reticulo-rumen. In comparison with the results of Care \& van't Klooster (1965) this represents a fourfold increase in $\mathrm{Mg}$ absorption at twice the rumen fluid $\mathrm{Mg}$ concentration, but in this instance the measurements were extended over several days on conscious, relatively normal animals.

Experiments based on the concentration ratios, digesta $\mathrm{Mg}$ : inert marker in the gut of slaughtered animals, in order to identify the sites of $\mathrm{Mg}$ absorption, have not produced consistent results. Perry, Cragle \& Miller ( 1967 ) found no $\mathrm{Mg}$ absorption from the rumen of calves, but the results reported by Marongiu (197I) indicate a considerable absorption of $\mathrm{Mg}$ from the rumen of sheep. However, although Marongiu (1971) found no absorption of $\mathrm{Mg}$ from the omasum, Perry et al. (1967) reported evidence to the contrary, although they dismissed this evidence as an artifact of their marker technique.

The suggestion that the omasum may be a significant site of $\mathrm{Mg}$ absorption in the ruminant stomach has been made by several authors (e.g. Rogers \& van't Klooster, 1969; Ben-Ghedalia, Tagari, Zamwel \& Bondi, 1975). This view is not supported by the evidence reported in this paper. It is possible that the method of introducing the $\mathrm{Mg}$ to the omasum may have confined the infused $\mathrm{Mg}$ to only a small area of the total omasal absorptive surface, particularly when the nature of the propulsive movements of the omasum is considered (Buéno \& Ruckebusch, 1974). If this were the situation the concentration gradient of $\mathrm{Mg}$ from this area of the omasal mucosa to blood would be very high. However, it seems highly likely that some of the infusate would have entered the omasal groove and then been distributed into most of the omasal lumen (Sellers \& Stevens, 1966), especially in view of the backflow of infusate to the rumen which occurred in one animal. Further, it is probable that much of the Mg leaving the rumen in normal circumstances moves rapidly to the abomasum through the omasal 
groove, and only a portion is moved through the interlaminar spaces of the omasum. Hence, if the omasum were the principal site of absorption of intraruminally infused $\mathrm{Mg}$, it seems likely that significant absorption would also be detected during the omasal infusion in this experiment.

The results of a number of studies have suggested that the omasum is a site for substantial absorption of volatile fatty acids, sodium, bicarbonate and water (Engelhardt \& Hauffe, 1975). Harrison (1971) found a small transfer of ${ }^{28} \mathrm{Mg}$ from the mucosal to the blood side of a portion of omasal lamella prepared in vitro. Also, absorption of Ca by omasal tissue in vitro has been reported (Timet, Herak, Emanovic \& Kraljevic, 1974), but concentrations higher than normal were used. Further, in view of the similarities in the epithelial lining and transmembrane potential difference between the rumen and omasum (Sellers $\&$ Stevens, I 966; Rogers $\&$ van't Klooster, 1969), the anatomical adaptation of the omasum for absorption (Lauwers, 1973), and the increased concentration of digesta minerals due to absorption of water, the possibility that some $\mathrm{Mg}$ is absorbed from the omasum should not be discarded. In particular, extrapolation of these results to cattle requires caution because of the relatively larger omasum in this species compared with sheep (Phillipson, 1970).

The lack of absorption of $\mathrm{Mg}$ from the abomasum in this study agrees with the results of Care \& van't Klooster (1965) from their experiments with gastric pouches in the sheep's abomasum, and also explains the apparent lack of absorption of $\mathrm{Mg}$ infused to the abomasum in the work of Pfeffer \& Rahman (1974).

Net $\mathrm{Mg}$ absorption from the intestines alone was insufficient to maintain both the plasma $\mathrm{Mg}$ levels and $\mathrm{Mg}$ balances which were obtained when absorption occurred from the whole gastrointestinal tract. These findings (Tables 2 and 3 ), for the relative apparent absorptive capacity of the stomach $v$. the intestines are consistent with those of other workers (Rogers \& van't Klooster, 1969; Pfeffer et al. 1970; Grace \& MacRae, 1972; Kemp et al. 1973; Pfeffer \& Rahman, 1974). Of course certain sections of the intestine, such as the mid-ileum and colon, are probably important areas of net $\mathrm{Mg}$ absorption, but these are largely nullified by the net secretion of $\mathrm{Mg}$ into other sections (Marongiu, 1971 ; Ben-Ghedalia et al. 1975). The over-all net absorption of Mg from the intestines is a balance between the absorptive and secretory processes, and may change under circumstances different from those imposed in the experiment here. There is no reason to suggest, however, that the $\mathrm{Mg}$ salts which were infused to the gut should have any specific perturbing effect on the $\mathrm{Mg}$ absorption processes.

Behar (1974) reported that in the rat intestine $\mathrm{Mg}$ appears to be transported principally by solvent drag, and this is directly related to the bulk water flow across the membrane, although a difference in the permeability of ileum and colon to $\mathrm{Mg}$ transfer by this mechanism was noted. However, the likely net transepithelial flux of water from the rumen (Engelhardt, 1970) is sufficient for only a small proportion of the estimated $\mathrm{Mg}$ absorption to occur in this manner since rumen fluid $\mathrm{Mg}$ levels averaged only $2.54 \mathrm{mmol} / 1$ during the intraruminal infusion. Similarly, for the omasum an average absorption rate of $700 \mathrm{ml}$ water/d (Engelhardt, 1970) could transport no more than about $\mathrm{I} \cdot 5 \mathrm{mmol} \mathrm{Mg} / \mathrm{d}$ by solvent drag. It appears that other transport mechanisms are responsible for $\mathrm{Mg}$ absorption from the rumen and, furthermore, 
the omasal infusion results suggest that the mucosa of the ruminant forestomach may not be freely permeable to the bulk flow transfer of $\mathrm{Mg}$.

The relatively unphysiological conditions imposed in many of the studies of $\mathrm{Mg}$ absorption from the rumen of sheep may have limited any transport processes involved and, coupled with the short-term nature of the experiments, led to the conclusion that absorption did not normally occur from this organ. Certainly the results presented here for sheep indicate a definite absorption of $\mathrm{Mg}$ from the reticulo-rumen, and that absorption from either the omasum or abomasum is not significant.

The authors wish to thank Mr M. T. Mano for his technical assistance and Mr W. B. Hall of CSIRO, Division of Mathematics and Statistics, for statistical analysis of the results.

\section{REFERENCES}

Behar, J. (1974). Am. F. Physiol. 227, 334 .

Ben-Ghedalia, D., Tagari, H., Zamwel, S. \& Bondi, A. (1975). Br. F. Nutr. 33, 87 .

Buéno, L. \& Ruckebusch, Y. (r974). F. Physiol., Lond. 238, 295.

Care, A. D. \& van't Klooster, A. Th. (1965). F. Physiol,, Lond. 177, I74.

Driedger, A., Condon, R. J., Nimrick, K. O. \& Hatfield, E. E. (1970). F. Anim. Sci. 3r, 772.

Engelhardt, W. v. (1970). In Physiology of Digestion and Metabolism in the Ruminant, p. 132 [A. T. Phillipson, editor]. Newcastle upon Tyne: Oriel Press.

Engelhardt, W. v. \& Hauffe, R. (1975). In Digestion and Metabolism in the Ruminant, p. 2 I6 [I. W. McDonald and A. C. I. Warner, editors]. Armidale, New South Wales, Australia: University of New England Publishing Unit.

Grace, N. D. \& MacRae, J. C. (1972). Br. F. Nutr. 27, 5 I.

Harrison, F. A. (1971). Phil. Trans. R. Soc. B 262, 301.

Kemp, A., van't Klooster, A. Th., Rogers, P. A. M. \& Geurink, J. H. (1973). Neth. F. agric. Sci. $21,44$. Lauwers, H. (1973). Meded. Fac. Diergeneesk. Rijks-Univ. Gent nos. I-2.

Marongiu, A. (1971). Boll. Soc. ital. Biol. Sper. 47, 768.

Perry, S. C., Cragle, R. G. \& Miller, J. K. (1967). ₹. Nutr. 93, 283.

Pfeffer, E. \& Rahman, K. A. (1974). Z. Tierphysiol. Tierernähr. Futtermittelk. 33, 209.

Pfeffer, E., Thompson, A. \& Armstrong, D. G. (1970). Br. F. Nutr. 24, 197.

Phillipson, A. T. (1970). In Duke's Physiology of Domestic Animals, 8th ed., p. 424 [M. J. Swenson, editor]. Ithaca, New York, USA: Cornell University Press.

Phillipson, A. T. \& Storry, J. E. (1965). 7. Physiol., Lond. 18r, 130.

Rogers, P. A. M. \& van't Klooster, A. Th. (1 969). Meded. LandbHoogesch. Wageningen r r, 26.

Sellers, A. F. \& Stevens, C. E. (1966). Physiol. Rev. 46, 634.

Stewart, J. \& Moodie, E. W. (1956). F. comp. Path. 66, Io.

Storry, J. E. (1961). F. agric. Sci., Camb. 57, 97.

Timet, D., Herak, H., Emanovic, D. \& Kraljevic, P. (1974). Vet. Arh. 44, 46.

Tomas, F. M., Jones, G. B., Potter, B. J. \& Langsford, G. L. (1973). Aust. F. agric. Res. $24,377$.

Tomas, F. M. \& Potter, B. J. (I975). Aust. F. agric. Res. 26, 585. 